\title{
Financial and Economic Factors Affecting Foreign Direct Investment - A Panel Estimation Study of the ASEAN-5 Countries
}

\author{
Geetha Subramaniam $^{1 *}$, Ratneswary Rasiah ${ }^{2}$, Doris Padmini Selvaratnam ${ }^{3}$ \\ and Jayalakshmy Ramachandran ${ }^{4}$ \\ ${ }^{1}$ SEGi University, Malaysia \\ Auckland Institute of Studies, New Zealand \\ ${ }^{2}$ Saito University College, Malaysia \\ ${ }^{3}$ Universiti Kebangsaan Malaysia \\ ${ }^{4}$ University of Nottingham Malaysia
}

\begin{abstract}
ASEAN's strength stems from its diversity, which generates a plethora of diverse market opportunities. Over the last few decades, Foreign Direct Investment (FDI) has risen significantly as a major source of international capital transfer, but the COVID-19 pandemic had a detrimental effect on FDI flows, with the outlook for ASEAN remaining highly unpredictable and contingent on the length of the crisis, the efficacy of policy efforts to encourage investment and to mitigate the economic consequences of the pandemic. This study examines the long-run relationships and shortrun dynamic interactions between FDI and its determinants comprising of market size, trade openness, stock market capitalisation and financial development over the period 1970 to 2019. The study applies the dynamic heterogeneous panel estimation techniques of Mean Group (MG), Pooled Mean Group (PMG) and Dynamic Fixed Effects (DFE) to analyse a set of macro panel data of the ASEAN-5 countries, to establish the possible relationships between these variables. An analysis of the results reveals the existence of a long-run causality between FDI and its predictors, indicated by the significant error correction terms for the models tested in this study. There is evidence that market size and stock market capitalization significantly contribute to FDI, with market size being the most dominant contributor. Interestingly, the study also reveals that trade openness and financial development are not significant in determining FDI in the selected countries. The study concludes with an examination of policy implications and also sheds some light on the outlook of FDI in ASEAN-5 post Covid 19.
\end{abstract}

Keywords: foreign direct investment, financial development, pooled mean group, ASEAN-5

\section{$\underline{\text { ARTICLE INFO }}$}

\section{Article History:}

Received: 23 July 2021

Accepted: 8 November 2021

Published: 1 December 2021

* Corresponding author: Geetha Subramaniam. Email: geethamaniam@gmail.com 


\section{INTRODUCTION}

Economists accept that Foreign Direct Investment (FDI) contributes significantly to economic performance and competitiveness. Being a major catalyst for development (OECD 2002), FDI successfully boosts the domestic economy by employment creation, technology transfer and spill-overs; while introducing new managerial and operational processes especially in the emerging economies. Studies show that market size, trade openness, infrastructural quality, human capital and labour productivity are the key attributes that contribute to FDI inflows (Hoang \& Bui, 2015). On the other hand, FDI outflows are associated with higher Gross Domestic Product (GDP), increased domestic savings, large foreign reserves and exports (Bano \& Tabbada, 2015). Developing countries enjoy benefits of capital flows in addition to other benefits like technology and employment as a result of FDIs (Karim et al., 2018).

In the context of the Association of Southeast Asian Nations (ASEAN), out of 12 member countries, Singapore is the only country listed as developed (UNDP, 2019) while the rest are categorised as developing nations (UN, 2020). ASEAN's diversity generates a plethora of diverse market opportunities which also implies that the determinants of FDI are unique to member nations. The European Union (EU) perceives the relationship with Southeast Asia which is enhanced through FDIs as very important, as it also further strengthens mutual economic dependence (Drzymala, 2013). It is also expected that the demand for healthcare services in ASEAN will result in higher investment in this sector within ASEAN (UNCTAD ASEAN Investment Report 2019). Although ASEAN member nations enjoy advantages of attracting FDIs, factors such as lack of regulatory framework for trade and investments as well as resistance of ASEAN member states to accept further economic integration hinders the ability of ASEAN markets to receive higher FDIs (Ziegenhain, 2020).

ASEAN, which was founded in 1967, by the five founder-member countries i.e Malaysia, Indonesia, Thailand, Singapore, and the Philippines and commonly referred to as ASEAN-5, aims to promote cooperation within its member nations to boost the economy and achieve economies of scale while trading within themselves. In 2019, FDI flowing into ASEAN-5 countries differed greatly. Singapore witnessed the highest FDI inflow with 
about US\$92.08 billion (92 percent of total FDI to the ASEAN region), followed by Indonesia at about US $\$ 23.56$ billion representing 24 percent of the total FDI. Other countries had comparatively very small inflows of FDI.

Due to the significant importance of FDI to the growth of ASEAN, it's imperative to examine the relationship of selected predictor variables on FDI, more so because most of these countries are greatly affected by COVID 19, which forms the motivation for this study.

The aim of this study is two pronged. Firstly, a panel data analysis was done to show the trend of FDI inflows and outflows of the ASEAN-5 countries from 1970 to 2019. Secondly, three estimation techniques were used to examine the long-run relationships and short-run dynamic interactions between FDI and its determinants comprising of market size, trade openness, stock market capitalization and financial development in the ASEAN-5 countries over the period 1970 to 2019.

\section{FDI TREND IN ASEAN-5}

Applying the Exponential Smoothing technique, the annual FDI inflows and outflows were plotted for the years 1970 until 2019 to see the trend pattern of FDI in the ASEAN-5 countries as illustrated in Figure 1. 

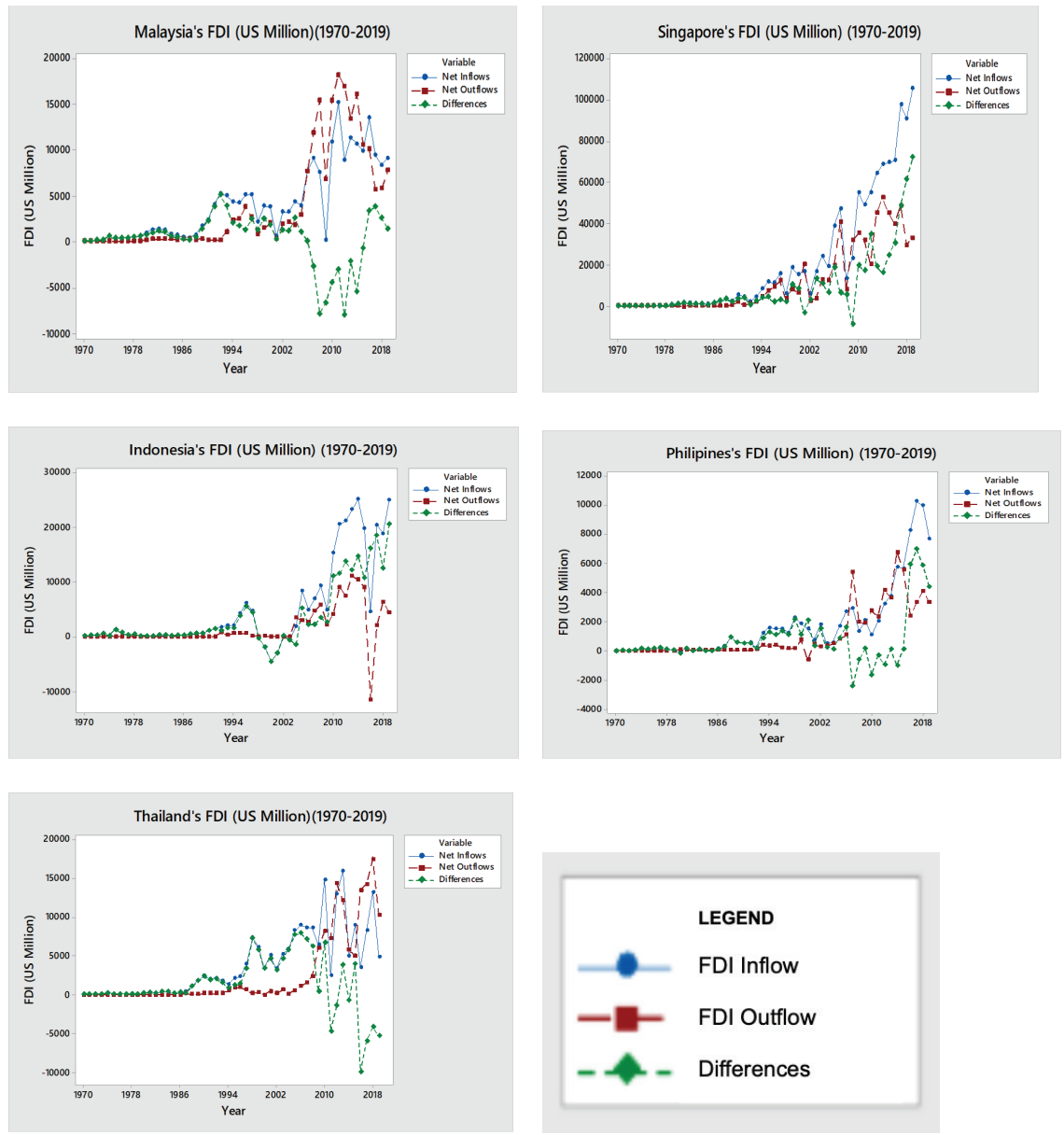

Figure 1: Foreign Direct Investment for ASEAN-5 (USD million), 1970 - 2019

Figure 1 shows the annual total FDI Inflow and total FDI outflow for Malaysia which shows an increasing trend from 1970 to 2019. But since 2002, the outflows were more than the inflows with a peak inflow in 2009.

Singapore's FDI also shows a general increasing trend since 1970. However, in some years, such as 2002 and 2010, Singapore experienced a deep drop in FDI, and the last five years show a very positive outlook. Indonesia, the largest member nation, had a FDI which portrays a constant flow initially for the first fourteen years from 1970. Since 1994, there seems 
to be an increasing trend with two sharp drops in 2002 and another one in 2017. But it seems so positive with an increasing trend since late 2017. FDI in the Philippines appears to be a constant slope. By 1988, the trends became clearer with upward and downward trends until 2019. As shown in Figure 1, the value of FDI Inflows and FDI outflows showed a slow increase until 1990 before declining in 2010. After that, the trends showed an upward and downward move in 2019.

The FDI trends in the ASEAN-5 countries generally had some similarity starting in a constant mode in 1970 but with the industrialisation policies and investment incentives, FDI increased in most countries since 1994. However, competition for scarce FDI from rising economies of China and India combined with the resurgence of the Latin American economies meant there was less resources for the ASEAN-5. Furthermore, in early May 1997, hopes of a Japanese recovery resulted in a strong yen appreciation and a rapid rise in Japanese short-term interest rates. Investors began withdrawing cash from Southeast Asian markets to take advantage of Japan's higher interest rates.

\section{LITERATURE REVIEW}

\section{Overview of FDls and its importance}

Pananond (2015) purports that the motives for FDI in an emerging market include strategies to expand into the international market as well as indulging in value-added activities along with lead firms in global value chains. For example, in Cambodia it was observed that FDI helps to transfer technology, promote 'learning by doing', train labour and result in spillovers of human skills and technology (Sokang, 2018). At the same time in China, Zhang (2001) evidenced that FDI assists China's transition and promotes income growth which seems to rise over time (Liu \& Lee, 2020), especially the increase in high-quality FDI in its logistics industry (Wang, 2011). Similar observations were also made in Bosnia and Herzegovina (Susic et al., 2017).

In Malaysia it was observed that FDI and human capital development play a significant role in the country's economic growth although technology 
spill-overs of FDI inflows are yet not evident providing policy implications to the government to take more efforts to attract FDIs (Fadhil \& Almsafir, 2015). Varma et al. (2020) evidenced an inimitable contribution of both private sector and state driven investment from India to Africa despite an adverse business environment, which has eventually contributed towards development of their manufacturing sector, improving employment opportunities as well as alleviating poverty and inequality issues in Africa.

\section{Key Determinants of FDI}

The key determinants of FDI have been researched by many and numerous contributions were made. Arawomo and Apanisile (2018) identify market size, trade openness, government expenditure, inflation and interest rate to be the key determinants whereas size of the host economy, government size, natural resources and the institutional variables were more relevant for MENA countries (Mohamed \& Sidiropoulos, 2010). Broadly for ASEAN countries macro-economic factors such as lower inflation, exchange rates, good governance as well as social attributes such as trade policies and transparency were documented (Ismail, 2009). As for ASEAN five it was purported that different countries had experienced varying factors during their stages of development although country specific variables broadly included skill \& knowledge, infrastructure and level of consumer income (Ho \& Rashid, 2011). More recent studies have helped to increase the understanding of other factors such as GDP, Import/Export, inflation, market size and infrastructure facility as having either a positive or negative impact on FDI suggesting that these factors influence FDI in ASEAN five (Van Rang, 2020; Xaypanya et al., 2015).

Despite such widespread positive thoughts about FDIs and its contributing effect to economic growth, it is claimed that the contribution of FDIs to economic growth is vague and countries that greatly benefit from FDIs are the ones that have a well-developed financial market (Alfaro et al., 2004). Emerging economies face a network of overlapping preferential trade agreements which impact their successes to experience regional trade integration (Asamoah et al., 2019). 


\section{Market Size}

Market size in this study is proxied by GDP per capita, constant 2010 US\$.

Oro and Alagidede (2021) note that FDI is generally recognised as being driven by market size and petroleum wealth in both developed and developing countries. Nevertheless, mining of mineral ore, backed by the availability of relatively cheap labour, is the main driver of FDI according to both panel and time-series data from the forty-nine African countries studied. In a recent study, Wang and Gul Rukh (2021) examined the impact of ICT accessibility on FDI inflow in D8 countries, namely, Bangladesh, Indonesia, Iran, Egypt, Nigeria, Malaysia, Pakistan and Turkey. The panel data study for the period 1997-2018, showed a positive and huge impact between ICT foundation and FDI inflows, alongside other controlling factors of market size and exchange receptiveness.

Loncan (2021) showed that larger projects tend to look at bigger market size and cheaper labour cost than lower corporate taxes and lower institutional distance, when deciding on emerging markets. Xaypanya et al. (2015) applied the first differencing method to appraise the boundaries on the developed panel data beginning from 2000 to 2011. Because of the various phases of monetary advancement somewhere in the range of ASEAN-3 and ASEAN-5, the determinants of FDI are unique and there are essentially constructive outcomes of framework, level of transparency, and adverse consequence of expansion on FDI inflows in ASEAN-3; while genuine conversion scale, total national output and net authority improvement help have no impact on its FDI. The findings in ASEAN5 showed that market size and foundation office are critical elements to pull in FDI. Even though there is an expansion in swelling rate just as a decline in degree of transparency estimation, ASEAN-5 is still alluring to unfamiliar financial backers. 


\section{Trade Openness}

Trade openness is calculated as exports plus imports as a percent of GDP.

Higher level of trade openness reduces the transaction costs and tends to attract FDI. The attractive risk-return international relationship implies none or reduced tariff and non-tariff barriers on investment and minimum problem in repatriating capitals as well as profits (Solow, 1957; Grossman \& Helpman 1991; and Barro \& Sala-I-Martin 1995). Nevertheless, trade openness may also actuate economic instability by increasing inflation, depreciating exchange rates and inviting a balance of payment crisis (Rodrik, 1992; Levine \& Renelt, 1992; Andriamananjara \& Nash, 1997; Adhikary, 2011).

Wang and Wang (2021) noted that with FDI as the threshold variable, the impact of trade openness on carbon intensity is negatively correlated. In addition, the impact of trade openness on carbon intensity is heterogeneous. In the high-income and lower-middle-income groups, trade openness reduces carbon intensity. On the other hand, in the upper-middle-income group, trade openness increases carbon intensity. A better understanding of the relationship between trade openness and carbon intensity provides theoretical support for countries to better use foreign trade activities to achieve low-carbon development. Cantah, et al. (2018) used the dynamic panel estimation technique to analyze the relationship between trade policy openness and FDI inflows in Sub-Saharan African countries where the results evidenced that an open economy attracts FDI.

Liargovas and Skandalis (2012) studied the significance of trade openness for pulling in FDI inflows, utilizing an example of 36 emerging economies for the period 1990-2008. It gives an immediate trial of causality between FDI inflows, exchange transparency and other key factors creating districts of the world: Latin America, Asia, Africa, CIS (Commonwealth of Independent States) and Eastern Europe. The principle experimental discoveries of the board relapse examination uncover that over the long haul, trade openness contributes decidedly to the inflow of FDI in developing economies. 


\section{Stock Market Capitalization}

The study of the relationship between Stock market affects and FDIs are crucial since stock markets are one of the key determinants of FDI. Stock markets affect the FDI flows providing signals which drive corporate investment decisions (De Santis \& Ehling, 2007). Capital markets are also contributors of productive investment for both developed and developing nations (Kalim et al., 2012). Authors have provided ample evidence on the contributions of FDI and foreign institutional investors on stock market volatility (Sultana \& Pradhasaradhi, 2012; Al Samman \& Jamil, 2018).

There exists little evidence on how stock market developments have impacted FDIs. For example, in Greece Tsagkanos et al. (2019) uniquely saw an overall weak relationship between stock market development and FDI suggesting a need for strong public administration; including fair tax policies particularly during any crisis period. However, in the long run there would be a definite positive relationship between stock market and FDIs for developing economies (Adam \& Tweneboah, 2009; Raza et al., 2012), which could differ between different sectors.

Soumare and Tchana (2015) evidenced a bidirectional causality between FDI and financial market development as a whole. However, in the banking sector the relationship remained inconclusive indicating that the financial markets were still in their infancy level; which could be the scenario in many developing and underdeveloped countries. At the same time the unidirectional relationship between stock market and FDI indicates a need for emerging economies to develop their stock markets to attract higher FDIs (Rajapakshe, 2018; BalaUmar et al., 2015). As such, there seems to be little evidence on the impact of the stock market on FDI in ASEAN-5 which we have analysed in this study.

\section{Financial Development through Domestic Credit to the Private Sector}

Public-private partnerships have always been encouraged to experience a win-win situation for host companies as well as foreign investors to achieve sustainable growth (Paramati et al., 2016). Domestic credit to the private sector indicates the financial assistance given to the private sector in support of their financial requirements through loans by 
financial institutions or banks; purchase of non-equity securities; and trade credits and other accounts receivable, that establish a claim for repayment (World Bank). Nezakati et al. (2011) and Fakhredin et al. (2011) evidence a positive relationship between Domestic Credit to Private Sector and FDI in Malaysia as well as other emerging economies (Duarte et al., 2017). There are other related advantages of providing credits for the private sector. In this context, Girma et al. (2008) found that access to credits by the private sector can boost innovations of domestic private sectors which is crucial to drive business success and sustainability. At the same time the benefits can be reaped by the private sector from the credits received only through 'efficient and effective utilization of borrowed funds' so that private sectors are able to achieve the desired objectives (Marshal et al., 2015). However, crises, particularly financial crises have a dampening impact of cross-border transactions due to lower domestic credits (Weitzel et al., 2014). The current COVID-19 pandemic has reduced cross-border transactions and hence testing this variable is imperative for the current study.

\section{RESEARCH METHODOLOGY}

The relationship between FDI and selected exploratory variables is examined in the ASEAN-5 countries of Malaysia, Indonesia, Thailand, Singapore, and the Philippines from 1970 to 2019. The data was obtained from the World Development Indicator of the World Bank. The summary of the variables used are shown in Table 1.

Table 1: Summary Details of Variables

\begin{tabular}{|c|c|c|c|}
\hline Variable & Descriptor & Data Source & $\begin{array}{l}\text { Expected } \\
\text { Sign }\end{array}$ \\
\hline $\begin{array}{l}\text { Foreign Direct } \\
\text { Investment }\end{array}$ & Foreign Direct Investment, billion USD & WDI, World Bank & $\mathrm{N} / \mathrm{A}$ \\
\hline Market Size & GDP per capita (constant 2010 US\$) & WDI, World Bank & + \\
\hline \multirow[t]{2}{*}{$\begin{array}{l}\text { Trade } \\
\text { Openness }\end{array}$} & $\begin{array}{l}\text { sum of exports and imports of goods and } \\
\text { services (constant } 2010 \text { US } \$ \text { ) }\end{array}$ & \multirow[t]{2}{*}{ WDI, World Bank } & \multirow[t]{2}{*}{+} \\
\hline & GDP at market prices (constant 2010 US\$) & & \\
\hline $\begin{array}{l}\text { Stock Market } \\
\text { Capitalization }\end{array}$ & Stock market capitalization, billion USD & WDI, World Bank & + \\
\hline $\begin{array}{l}\text { Financial } \\
\text { development }\end{array}$ & Domestic credit to private sector (\% of GDP) & WDI, World Bank & + \\
\hline
\end{tabular}


As suggested by Pesaran and Smith (1995), three separate estimation strategies for dynamic heterogeneous macro panel data were used: Mean Group (MG), Pooled Mean Group (PMG), and Dynamic Fixed Effect (DFE). Traditional panel estimation techniques such as fixed effect, instrumental variables, and Generalised Methods of Moment (GMM) could result in inconsistent and potentially misleading estimates of the average values of the parameters in a heterogeneous panel in the case of large $\mathrm{T}$, violating the pooling assumption. The PMG estimation technique as suggested by Pesaran, Shin and Smith (1999), is able to establish the short-run and long-run causality among the variables used in this study, by allowing the short-run coefficients and error variances to differ across groups in the cross-section, while maintaining long-run homogeneity across all slope coefficients. This research uses the MG (Pesaran \& Smith, 1995) and DFE estimation techniques in a multi-model system for comparison and to verify the robustness of the findings.

The logarithmic version for our baseline estimation model, with a given data on time periods of $t=1,2, \ldots, \mathrm{T}$ and number of countries of $\mathrm{i}=$ $1,2, \ldots ., \mathrm{N}$, the PMG is generated from a generally-specified Autoregressive Distributed Lag (ARDL) (p, q, q, ...., q) model which can be written as follows:

$$
L F D I_{i t}=\sum_{j=1}^{p} \lambda_{i j} L F D I_{i, t-j}+\sum_{j=0}^{q} \gamma_{i j}^{\prime} X_{i, t-j}+\mu_{i}
$$

where $X_{i, t-j}$ is the (k x 1) vector of explanatory variables for group $i$ which comprises of GDP per capita, trade openness, financial development and inflation rate; while $u i$ represents the fixed effects; $\lambda_{\mathrm{ij}}$, are scalars representing the coefficients of the lagged dependent variables; and $\gamma_{\mathrm{ij}}$ are $\mathrm{kx} 1$ coefficient vectors. This study will also estimate the model for each individual group separately, as $t$ is large.

We re-parameterized equation (1) to estimate the general errorcorrection equation as follows: 


$$
\begin{aligned}
& \Delta L F D I_{i t}=\emptyset_{i} L F D I_{i, t-1}+\beta_{i}^{\prime} X_{i t}+\sum_{j=1}^{p-1} \quad \lambda_{i j}^{*} \Delta L F D I_{i, t-j}+ \\
& \sum_{j=0}^{q-1} \quad \gamma_{i j}^{* \prime} \Delta X_{i, t-j}+\mu_{i}+\varepsilon_{i t}
\end{aligned}
$$

where $\phi_{i}=-\left(1-\sum_{j=1}^{p} \quad \lambda_{i j}\right)$ and $\beta_{i}=\sum_{j=0}^{q} \quad \gamma_{i j}$ and $\lambda_{i j}^{*}=$

$-\sum_{m=j+1}^{p} \lambda_{i m}, \mathrm{j}=1,2, \ldots, \mathrm{p}-1$,

and $\gamma_{i j}^{*}=-\sum_{m=j+1}^{q} \quad \gamma_{i m}, \mathrm{j}=1,2, \ldots, \mathrm{q}-1$.

This study will estimate the error correction and cointegration model for foreign direct investment by specifying the following ARDL (p, q1, q2, q3, q4) model so that the long-run and short-run adjustments can be obtained. Equation 3 shows the ARDL unrestricted error-correction equation:

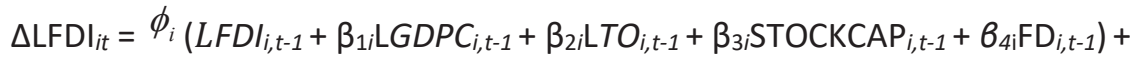
$\sum_{j=1}^{p-1} \quad \lambda_{i j}^{*} \Delta L F D I_{i, t-j}+\sum_{j=1}^{p-1} \quad \lambda_{i j}^{*} \Delta$ lnHappiness $s_{i, t-j}$

$\sum_{j=0}^{q_{1}-1} \quad \gamma_{1 i j}^{*} \Delta L G D P C_{i, t-j} \sum_{j=0}^{q_{1}-1} \quad \gamma_{1 i j}^{*} \Delta \ln G D P p c_{i, t-j}+$

$\sum_{j=0}^{q_{1}-1} \quad \gamma_{1 i j}^{*} \Delta \ln G D P p c_{i, t-j}+\sum_{j=0}^{q_{2}-1} \quad \gamma_{2 i j}^{*} \Delta L T O_{i, t-j}+$

$\sum_{j=0}^{q_{2}-1} \quad \gamma_{2 i j}^{*} \Delta \operatorname{lnUnemp} \operatorname{lit}_{i, j}+\sum_{j=0}^{q_{1}-1} \gamma_{1 i j}^{*} \Delta \operatorname{lnGDPpc_{i,t-j}+}$

$\sum_{j=0}^{q_{3}-1} \quad \gamma_{3 i j}^{*} \Delta$ LSTOCKCAP ${ }_{i, t-j}+\sum_{j=0}^{q_{4}-1} \quad \gamma_{4 i j}^{*} \Delta F D_{i, t-j}++\varepsilon_{i t}$

for $\mathrm{i}=1,2, \ldots \mathrm{N}$ and $\mathrm{t}=1,2, \ldots . \mathrm{T}$; while $\phi_{i}=-\left(1-\sum_{j=1}^{p} \quad \lambda_{i j}\right) ; \beta_{1 i}=$ $\sum_{j=0}^{q 1} \quad \gamma_{1 i j}$

The Akaike Information Criterion (AIC) and Schwarz Bayesian Criterion (SBC) was employed to conduct lag selection. Following Pesaran et al. (1999), the estimation equation (3) can be re-written as an error correction representation of the ARDL model as follows:

$\Delta \mathrm{LFDI}_{2 i t}=\phi_{i}\left(\mathrm{LFDI}_{2 i, t-1}-\beta_{0 i}-\beta_{1 i} \mathrm{LGDPC}_{i t}-\beta_{2 i} L T O_{i t}-\beta_{3 i} \mathrm{LSTOCKCAP}_{i t}\right.$

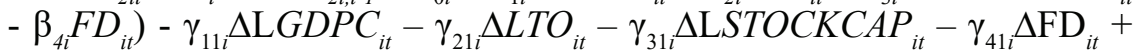
$\varepsilon_{i t}$ 
where

$\beta_{0 i}=\frac{\mu_{i}}{1-\lambda_{i}} ; \quad \beta_{1 i}=\frac{\gamma_{10 i}+\gamma_{11 i}}{1-\lambda_{i}} ; \quad \beta_{2 i}=\frac{\gamma_{20 i}+\gamma_{21 i}}{1-\lambda_{i}} ; \quad \beta_{3 i}=\frac{\gamma_{30 i}+\gamma_{31 i}}{1-\lambda_{i}} ; \quad \beta_{4 i}=$ $\frac{\gamma_{40 i}+\gamma_{41 i}}{1-\lambda_{i}}$

and $\phi_{i}=-\left(1-\lambda_{i}\right)$

The coefficient of the error correction term $\phi_{i}$ represents the speed of adjustment of $\ln F D I$ towards its long-run equilibrium following the shock to the short-run.

\section{RESULTS AND DISCUSSION}

Prior to estimating the determinants of FDI, it is necessary to describe the features or characteristics of the data utilised in this empirical research. Table 2 contains the descriptive or summary statistics for all variables utilised in this study.

Table 2: Descriptive Statistics

\begin{tabular}{|c|c|c|c|c|c|c|c|c|}
\hline Variable & & Mean & $\begin{array}{l}\text { Std. } \\
\text { Dev. }\end{array}$ & Min & Max & Skewness & Kurtosis & Obs. \\
\hline & overall & & 1.824 & -4.605 & 4.658 & -.370 & 2.992 & \\
\hline \multirow[t]{3}{*}{ LFDI } & between & 0.791 & 0.858 & -0.331 & 2.059 & & & 219 \\
\hline & within & & 1.651 & -3.483 & 3.451 & & & \\
\hline & overall & & 1.093 & 6.855 & 10.987 & .830 & 2.662 & \\
\hline \multirow[t]{3}{*}{ LGDPC } & between & 8.420 & 1.110 & 7.526 & 10.231 & & & 225 \\
\hline & within & & 0.454 & 7.366 & 9.192 & & & \\
\hline & overall & & 0.732 & 3.619 & 6.081 & .467 & 1.912 & \\
\hline \multirow[t]{3}{*}{ LTO } & between & 4.673 & 0.763 & 3.936 & 5.847 & & & 225 \\
\hline & within & & 0.261 & 3.946 & 5.303 & & & \\
\hline & overall & & 1.182 & 2.404 & 6.669 & -.271 & 1.892 & \\
\hline \multirow[t]{3}{*}{ LStockCap } & between & 4.764 & 0.187 & 4.423 & 4.901 & & & 160 \\
\hline & within & & 1.172 & 2.359 & 6.623 & & & \\
\hline & overall & & 0.660 & 2.270 & 5.115 & -.379 & 2.080 & \\
\hline \multirow[t]{2}{*}{ LFD } & between & 4.060 & 0.601 & 3.378 & 4.516 & & & 210 \\
\hline & within & & 0.386 & 2.935 & 4.790 & & & \\
\hline
\end{tabular}


The within variance component explains slightly more of the variability in the data for FDI and stock market capitalisation compared with the between variance component. As seen in Table 2 for FDI, the overall variance is $1.824^{2}(=3.327)$, of which the between variance is $0.858^{2}$ $(=0.736)$, which indicates that only $22.12 \%$ of the overall variability in the data occurs between countries.

The between variance component explains slightly more of the variability in the data for income, trade openness and financial development compared with the within variance component. As seen in Table 2 for GDPC, the overall variance is $1.093(=1.195)$, of which the within variance is 0.454 $(=0.206)$, which indicates that only $17.24 \%$ of the overall variability in the data occurs within-country.

Hair et al. (2010) argued that data is considered to be normal if skewness is between -2 to +2 and kurtosis is between -7 to +7 . The results shown in Table 2 demonstrate that the skewness value is between -0.271 to 0.830 and kurtosis value is between 1.892 to 2.992 . This indicate that all model variables are congregated to normality.

The pairwise correlation matrix for the main variables of the FDI model are shown in Table 3. All variables are shown to be positively correlated with foreign direct investment, concurring with most FDI studies.

Table 3: Correlation Matrix for the Key Variables of the FDI Model

\begin{tabular}{llcccc}
\hline & LFDI & LGDPC & LTO & LStockCap & LFD \\
\hline LFDI & 1.000 & & & & \\
LGDPC & 0.547 & 1.000 & & & \\
LTO & 0.262 & 0.888 & 1.000 & & \\
LStockCap & 0.743 & 0.330 & 0.032 & 1.000 & \\
LFD & 0.229 & 0.450 & 0.516 & 0.257 & 1.000 \\
\hline
\end{tabular}

While it is conceivable that the different variables under investigation have a positive or negative correlation with one another, this does not mean that any single variable has a causal influence on another. Further empirical investigation is required to validate or refute the correlation values in Table 
3 using additional panel estimation approaches before any conclusions were drawn.

The first step in analysing a macro panel dataset is to ascertain whether the estimated equations are cointegrated, through determining the stationarity of the variables in the study, prior to estimating the FDI equation. To check for the existence of unit roots in the study's panel data set, the Im, Pesaran, and Shin or IPS $(1997,2003)$ test and the Maddala-Wu or MW (1999) test were used. Table 4 confirms that all variables are non-stationary at level and stationary at first difference at a $1 \%$ level of significance, for both the IPS and the MW tests. Therefore, all variables in this study are $\mathrm{I}(1)$; that is, integrated of order 1 .

Table 4: Im-Pesaran-Shin (2003) and Maddala and Wu (1999) Panel Unit Root Test

\begin{tabular}{lcccc}
\hline & \multicolumn{2}{c}{ IPS } & \multicolumn{2}{c}{ MW (Fisher-ADF) } \\
\hline \multicolumn{1}{c}{ Variable } & Level & First Difference & Level & First Difference \\
\hline LFDI & $0.4120[1]$ & $-11.2856[1]^{* * *}$ & $7.6706[1]$ & $161.741[1]^{* * *}$ \\
LGDPC & $1.8403[1]$ & $-6.7164[1]^{* * *}$ & $5.4490[1]$ & $76.326[1]^{* * *}$ \\
LTO & $-1.0659[1]$ & $-7.3200[1]^{* * *}$ & $12.6562[1]$ & $86.8000[1]^{* * *}$ \\
LSTOCKCAP & $1.2952[1]$ & $-8.1072[1]^{* * *}$ & $3.7836[1]$ & $102.5090[1]^{* * *}$ \\
LFD & $-0.7844[1]$ & $-5.7904[1]^{* * *}$ & $11.1295[1]$ & $60.9577[1]^{* * *}$ \\
\hline
\end{tabular}

Notes: 1. The numbers in parentheses represent the $p$-values.

2. The asterisks ${ }^{* \star *}$ and ${ }^{* *}$ indicate the rejection of unit root null hypothesis at $1 \%$ and $5 \%$ of significance levels, respectively.

3. Probabilities for the MW (Fisher-ADF) test are computed using an asymptotic Chi-square distribution. IPS test assumes asymptotic normality.

The dynamic estimation techniques of MG, PMG and DFE are carried out upon confirmation that all variables are stationary at first difference. Table 5 reports the short-run and long-run coefficients as well as the error-correction terms for the baseline and full models using the abovementioned estimation techniques. Table 5 reveals the results of Model 1, the baseline model that utilises the control variables which impact foreign direct investment, and Model 2, the full model that captures financial development. The control variables include market size (LGDPC), trade openness (LTO), and stock market capitalisation (LSTOCKCAP). In Model 2 , financial development (FD) is added to the control variables to analyse 
their relationship to the dependent variable (LFDI). The two specifications (models) with varying sets of explanatory variables were analysed, revealing generally valid results in accordance with the literature on FDI. The coefficients' signs and magnitudes are mostly similar across the three estimators, as shown in Table 5.

In both the baseline and full models that specifically explain FDI; market size and stock capitalization have significant long-run coefficients, while trade openness and financial development do not. Additionally, considering the use of two separate models, Table 5 demonstrates that the results are fairly consistent and robust across all three estimation techniques, indicating that the chosen predictors are cointegrated with FDI. The MG estimation technique is the least restrictive method as it allows for parameter heterogeneity, therefore rendering the MG estimates as potentially not efficient. The PMG estimation technique, on the other hand, as an intermediate estimator between the MG and DFE estimators, allows for differences in intercepts, short-run coefficients, and error variances while requiring long-run homogeneity for all slope coefficients. The DFE estimator, however, allows only for differences in intercepts across countries.

The Hausman test was used to test long-run homogeneity, and the results show that the PMG estimator is more consistent and efficient than the MG estimator, with standard errors that are much smaller. When the PMG estimation technique is used instead of the $\mathrm{MG}$ estimation technique, the error-correction term (or convergence coefficient) is greatly reduced. When the DFE estimation method is used, it restricts the short-term dynamics, which affects the direction and significance of the long-run coefficients.

The PMG estimator is the most superior estimator, according to the Hausman test results in Table 5, as it is the most consistent and efficient. The findings suggest that there is long-run causality between foreign direct investment and its predictors, as shown by the significant error correction terms for both models. The magnitude of the speed of adjustment is fairly high for both models ( 0.767 and 0.775 , respectively), indicating that to restore long-run equilibrium, approximately 77 percent adjustment or correction takes place in one year for Model 1 and approximately 78 percent adjustment takes place for Model 2. 
Table 5: Estimated Long-run Coefficients and Speed of Adjustment

\begin{tabular}{|c|c|c|c|c|c|c|}
\hline \multirow[t]{2}{*}{$\begin{array}{c}\text { Dependent } \\
\text { variable: LFDI }\end{array}$} & \multicolumn{3}{|c|}{$\begin{array}{c}\text { Model } 1 \\
\text { (Baseline) }\end{array}$} & \multicolumn{3}{|c|}{$\begin{array}{l}\text { Model } 2 \text { (Full } \\
\text { Model) }\end{array}$} \\
\hline & (1) & $(2)$ & (3) & (4) & (5) & (6) \\
\hline & $\begin{array}{l}\text { Mean } \\
\text { Group } \\
\text { (MG) }\end{array}$ & $\begin{array}{l}\text { Pooled Mean } \\
\text { Group (PMG) }\end{array}$ & $\begin{array}{l}\text { Dynamic } \\
\text { Fixed } \\
\text { Effects } \\
\text { (DFE) }\end{array}$ & $\begin{array}{l}\text { Mean } \\
\text { Group } \\
\text { (MG) }\end{array}$ & $\begin{array}{l}\text { Pooled Mean } \\
\text { Group (PMG) }\end{array}$ & $\begin{array}{c}\text { Dynamic } \\
\text { Fixed Effects } \\
\text { (DFE) }\end{array}$ \\
\hline \multicolumn{7}{|c|}{ Long-run coefficients } \\
\hline \multirow[t]{2}{*}{ LGDPC } & $1.549^{* * *}$ & $1.907^{* * *}$ & $2.0911^{* * *}$ & 0.979 & $1.764^{* * *}$ & $1.833^{*}$ \\
\hline & $(0.333)$ & $(0.424)$ & $(0.607)$ & $(0.972)$ & $(0.480)$ & $(0.719)$ \\
\hline \multirow[t]{2}{*}{ LTO } & 0.936 & -0.0489 & 0.0756 & $1.702^{*}$ & -0.0773 & -0.0749 \\
\hline & $(0.536)$ & $(0.323)$ & $(0.349)$ & $(0.701)$ & $(0.344)$ & $(0.383)$ \\
\hline \multirow[t]{2}{*}{ LSTOCKCAP } & $0.4425^{\star}$ & $0.3920^{* *}$ & 0.1828 & 0.558 & $0.397^{\star \star}$ & 0.281 \\
\hline & $(0.219)$ & $(0.133)$ & $(0.186)$ & $(0.341)$ & $(0.144)$ & $(0.218)$ \\
\hline \multirow[t]{2}{*}{ LFD } & & & & 0.842 & 0.423 & -0.0965 \\
\hline & & & & $(0.439)$ & $(0.348)$ & $(0.412)$ \\
\hline $\begin{array}{l}\text { Error } \\
\text { correction } \\
\text { coefficient }\end{array}$ & $\begin{array}{c}-1.020^{* * *} \\
(0.0638)\end{array}$ & $\begin{array}{c}-0.767^{\star \star *} \\
(0.0841)\end{array}$ & $\begin{array}{c}-0.791^{* * *} \\
(0.0811)\end{array}$ & $\begin{array}{c}-1.168^{* * *} \\
(0.140)\end{array}$ & $\begin{array}{c}-0.775^{\star * *} \\
(0.0940)\end{array}$ & $\begin{array}{l}-0.801^{* \star *} \\
(0.0850)\end{array}$ \\
\hline \multicolumn{7}{|c|}{ Short-run coefficients } \\
\hline \multirow[t]{2}{*}{$\triangle \mathrm{LGDPC}$} & 3.168 & 5.612 & $4.086^{*}$ & -3.918 & 3.836 & $3.981^{*}$ \\
\hline & $(3.523)$ & $(4.762)$ & $(1.719)$ & $(8.140)$ & $(2.553)$ & $(1.857)$ \\
\hline \multirow[t]{2}{*}{$\Delta \mathrm{LTO}$} & 0.186 & 1.741 & 1.403 & -1.326 & 1.960 & 1.294 \\
\hline & $(0.758)$ & $(0.904)$ & $(0.749)$ & $(1.533)$ & $(1.200)$ & $(0.799)$ \\
\hline \multirow[t]{2}{*}{$\triangle \mathrm{LSTOCKCAP}$} & -0.251 & -0.107 & -0.0174 & -0.399 & -0.052 & -0.111 \\
\hline & $(0.186)$ & $(0.0635)$ & $(0.155)$ & $(0.379)$ & $(0.110)$ & $(0.177)$ \\
\hline \multirow[t]{2}{*}{$\Delta \mathrm{LFD}$} & & & & $-0.126^{* * *}$ & -0.176 & -0.859 \\
\hline & & & & $(0.385)$ & $(0.570)$ & $(0.695)$ \\
\hline \multirow[t]{2}{*}{ Constant } & $-17.98^{* * *}$ & $-12.97^{* * *}$ & $-14.44^{\star * *}$ & $-21.05^{\star * *}$ & $-13.36^{* * *}$ & $-12.23^{*}$ \\
\hline & $(3.413)$ & $(1.861)$ & $(3.965)$ & $(5.747)$ & $(2.118)$ & $(4.851)$ \\
\hline $\begin{array}{l}\text { No. of } \\
\text { countries }\end{array}$ & 5 & 5 & 5 & 5 & 5 & 5 \\
\hline Observations & 148 & 148 & 148 & 138 & 138 & 138 \\
\hline Hausman test & & 0.4564 & & & 0.1 & \\
\hline
\end{tabular}

Notes: 1. The numbers in parentheses are standard errors.

2. The asterisks ${ }^{* * *},{ }^{* *}$, and ${ }^{*}$ indicate the rejection of null hypothesis at $1 \%, 5 \%$, and $10 \%$ of significance levels, respectively.

The results of the PMG estimation technique was found to be the most effective, where the long-run coefficient for market size is significantly positive, indicating that market size is one of the important factors that encourages FDI into the selected ASEAN-5 countries.

The positive long-run relationship between stock market capitalization and FDI as revealed in this study concurs with the findings of Yadav, Pahi, 
and Gangakhedkar (2019); Kariuki (2015); and Al-Khouri (2015). As for the role of trade openness, this study did not find it to be a significant predictor of FDI. The findings on the insignificant financial developmentFDI relationship concurred with those of Kasasbeh, Mdanat, and Khasawneh (2018).

It can be observed that the long-run causality between market size and FDI is stronger followed by stock market capitalisation implying that increase in market size can lead to increased FDI. This finding conforms to that of Nasir (2016) who evidenced that in Malaysia, market size played a significant role in enhancing FDIs. The findings provide an extended view by emphasising that market size will have an impact on ASEAN-5 countries where most of these economies are still emerging. This result also clearly aligns with the findings of Nguyen and Lee (2021); Azam and Haseeb (2021); Canh et al. (2020); Shan et al. (2018), and Kawai and Naknoi (2017).

Stock market capitalisation is also found to have a significant positive relationship with FDI implying that more matured stock markets would be able to attract higher FDIs. However, most stock markets in ASEAN countries are considered small. While this might deter FDIs from flowing in, a better regulation and governance of the stock market could help attract more FDI which can be evidenced in the case of Singapore. Public administration and governance were the key barriers to stock market development as evidenced by Tsagkanos et al. (2019) in Greece, to which the findings concur. It is generally understood that most countries in ASEAN and also broadly in Asia suffer and lose opportunities as a result of poor governance and weak regulatory health although they do have advantages of cheap resources.

This study did not reveal any significant relationship between financial development and long-run effect on FDI. While this could be contradicting many studies which established a positive relationship (Nguyen \& Lee, 2021; Akisik, 2020; and Aziz \& Mishra, 2016) or the less frequent negative relationship (Anyanwu \& Yameogo, 2015) between financial development and FDI, claims are made that beyond a certain threshold level of financial development, the unidirectional impact of financial development on FDI could turn negative unless countries can establish political stability (Dutta \& Roy, 2011). Although untested in this research, the findings can draw a close 
relevance to Dutta and Roy (2011) since most ASEAN countries greatly suffer from political instability. This is one of the key concerns identified during the ongoing COVID 19 pandemic and post crisis development (Lee, 2020).

The study also draws a serious impact on Malaysia as a result of the current political uncertainties followed by Thailand which is facing similar issues. These findings have a strong practical implication particularly for countries (example Malaysia) that are on the border of transiting from an emerging economy to developed nation.

Finally, there is no significant relationship between trade openness and FDI, which is similar to the findings of Kasasbeh, Mdanat, and Khasawneh (2018) for the Jordanian economy, and Kinuthia and Murshed (2015) for Kenya, and contrary to the findings of Azam and Haseeb (2021) for the BRICs countries, Mina (2020) for the GCC countries and Huong, Nguyen, and Lien, (2020) for Vietnam. We also drew reflections from another study undertaken in Vietnam by NGO et al. (2020) which is quite in contrast to Huong, Nguyen, and Lien (2020) suggesting that trade openness is not seen as an attraction by developed countries into Vietnam and one of the reasons cited is the fact that attractions of Vietnam are shadowed by their neighbours China on one hand Vietnam on the other is perhaps not perceived as a perfect market economy deterring FDIs.

Malaysia and Thailand might be facing a similar scenario where the attractions and other macroeconomic factors could be overpowering Malaysia. Hence despite the uniqueness that Malaysia and Thailand can offer in terms of capital financing, exchange rate benefits as well as Malaysia's leadership in Shariah financing, these could be shadowed by the attractiveness of our neighbours. As noted in the earlier paragraph, political instability, corruption and poor governance could also make these countries less attractive despite the trade openness.

\section{COVID-19 IMPACT ON FDI}

The COVID-19 pandemic has been tough on almost all the economies with growth stalling in most industries. The impact can be quite severe on 
under-developed and developing economies, especially if the government does not manage the economic, financial, and legislative aspects well (Hejazi \& Tang, 2021). As per the UN report the COVID-19 pandemic has caused a reduction in investment flows to Asian countries between $30 \%$ to $45 \%$. It is also noted that FDI inflows to developing countries are expected to reduce further since sectors that felt the heat of pandemic account for a bigger share of their FDI than in developed economies. Countries can use a sustainable investment framework as drivers for sustainable FDIs alongside digital FDIs which include internationally acceptable guidelines, corporate social responsibility (CSR) Programmes, sustainability reporting, alignment of behaviours with incentives, sustainability of investment in infrastructure and steps to improve linkages by local firms with foreign investors (Stephenson, 2020).

Despite the predictions that COVID 19 can negatively impact FDIs, ASEAN-5 member countries are showing a propensity to stay complacent or in some cases show increased benefits resulting from favourable trade agreements between member nations. Countries that are likely to be impacted negatively should take into consideration issues such as security, regulatory compliance and take advantage of low labour costs to attract more foreign investment. As explained earlier, COVID 19 pandemic has caused serious challenges particularly for the ASEAN-5 region in attracting FDIs.

This might mean good news for these countries since the COVID 19 is known to have a negative impact on FDIs of emerging economies. Thus, the ability to sustain during the pandemic through international trade relations is crucial for emerging economies. While Singapore is likely to witness a steep increase in their FDIs, the other four countries might witness a mild decrease in their FDIs. One of the reasons could be due to the tourism industry, which stalled during the pandemic; can be revived once the vaccination programmes are implemented. Among the countries in the ASEAN-5 region, Indonesia could be the worst affected and the government must take adequate measures to benefit greatly from trade flexibilities in ASEAN. 


\section{CONCLUSION AND POLICY IMPLICATION}

The objectives of this study were, firstly to perform a trend analysis on FDI inflows and outflows among the ASEAN-5 member nations; and secondly to examine the relationship between FDI and selected exploratory variables in the ASEAN-5 countries. Using the data from the World Bank, some interesting results emerged.

First objective was achieved using panel data analysis which shows that Malaysia was witnessing a steady FDI from 1970 until the early 1990s, even though there were fluctuations in the FDIs (both inflows and outflows). A similar trend was seen for Thailand, Indonesia and Philippines until 2019. On the contrary, Singapore witnessed a steady increase in their FDIs with an observable increase in their FDIs until 2019. One of the reasons could be the regulatory compliance and strong governance which is one of the ways countries can attract FDIs. In fact, Singapore's ability to attract FDI may have been aided by a general lack of openness, cronyism, and other factors in the conduct of economic activity in several ASEAN countries. Besides, five major investments from Australia related to health-care services and technology solutions are concentrated in Singapore and Malaysia.

To achieve the second objective, three separate estimation techniques for dynamic heterogeneous macro panel data were conducted between the four predictor variables and FDI using the Mean Group, Pooled Mean Group and Dynamic Fixed Effects estimators. The results taken from the most efficient Pooled Mean Estimator revealed that out of the four predictors tested, market size and stock market capitalisation were significant while financial development and trade openness were found to be insignificant to attract FDIs.

This implies that ASEAN-5 regions have to expand their market and strengthen the stock markets through better administration and regulation to attract higher FDIs. While a number of studies have contributed to understanding the positive impact of trade openness on FDIs, this study did not find an impact within the ASEAN-5 region, either in the short-run nor in the long-run. Similarly, the level of financial development of the host country can most likely attract higher FDIs as per past studies whereas this study does not provide adequate support. Much of these findings have a 
bearing on weak governance and regulation followed by political instability which are pertinent in most ASEAN countries.

Overall, it can be seen that countries in the ASEAN-5 region have different growth prospects and the ways in which FDIs can contribute towards the growth of these countries.

This study contributes to a better understanding of FDI inflow trends in the last 30 years among ASEAN 5 countries. Additionally, the study provides a few policy implications.

Firstly, market size for the 21 st century products related to ICT, digital technology, healthcare and pharmaceutical R\&D and investment in agedcare might be sectors ASEAN-5 should explore and expand. The ASEAN-5 countries need to re-look at sectors that need to open and also the products that will best benefit member countries in the trade openness initiative. A better trade relationship can be established by ensuring that critical resources like medicine and food are made more available within member countries.

Next, in the long run, countries should work on stabilising the political uncertainties to draw benefits through FDIs from developed nations.

Thirdly, ASEAN-5 countries should take active action to reduce bureaucracy and increase transparency. This means facilitating the process of acquiring information, contracts and transaction processes making it more effective and efficient. In this regard, tariffs and taxes that could burden member countries or cause an indirect pressure to some of the emerging economies can be avoided until the situation is stabilised.

ASEAN-5 nations should work together in providing additional benefits to member nations to enjoy a mutual benefit as well as boost economic growth through FDIs. Strategies and policies that encourage this development with an emphasis on human capital development towards utilising domestic and foreign investment will be timely for Malaysia and other ASEAN countries. 


\section{REFERENCES}

Adam, A. M., \& Tweneboah, G. (2009). Foreign direct investment and stock market development: Ghana's evidence. International Research Journal of Finance and Economics, 26, 178-185.

Adhikary, B. K. (2011). FDI, trade openness, capital formation, and economic growth in Bangladesh: A linkage analysis. International Journal of Business and Management, 6(1), 16.

Akisik, O. (2020). The impact of financial development, IFRS, and rule of LAW on foreign investments: A cross-country analysis. International Review of Economics \& Finance, 69, 815-838.

Al Samman, H., \& Jamil, S. A. (2018). The Impact of Foreign Direct Investment (FDI) on Stock Market Development in GCC countries. Pertanika Journal of Social Sciences \& Humanities, 26(3).

Al-Khouri, R. (2015). Determinants of foreign direct and indirect investment in the MENA region. The Multinational Business Review, 23(2), 148166.

Andriamananjara, S., \& Nash, J. (1997). Have Trade Policy Reforms Led to Greater Openness in Developing Countries? Evidence from Readily Available Trade Data (Vol. 1730). World Bank Publications.

Anyanwu, J. C., \& Yameogo, N. D. (2015). What drives foreign direct investments into West Africa? An empirical investigation. African Development Review, 27(3), 199-215.

Arawomo, O., \& Apanisile, J. F. (2018). Determinants of foreign direct investment in the Nigerian telecommunication sector. Modern Economy, 9(05), 907.

Azam, M., \& Haseeb, M. (2021). Determinants of foreign direct investment in BRICS does renewable and non-renewable energy matter? Energy Strategy Reviews, 35, 100638. 
Aziz, O. G., \& Mishra, A. V. (2016). Determinants of FDI inflows to Arab economies. The Journal of International Trade \& Economic Development, 25(3), 325-356.

BalaUmar, M., Ismail, S., \& Sulong, Z. (2015). The Impact of Stock Market Development on Foreign Direct Investment in Nigeria: An Application of Autoregressive Distributed Lag Model. Scholars Journal of Economics, Business and Management, 2(4), 400-411.

Barro, R. J., Mankiw, N. G., \& Sala-i-Martin, X. (1995). Capital mobility in neoclassical models of growth. The American Economic Review, 103-115.

Canh, N. P., Binh, N. T., Thanh, S. D., \& Schinckus, C. (2020). Determinants of foreign direct investment inflows: The role of economic policy uncertainty. International Economics, 161, 159-172.

Cantah, G. W., Brafu-Insaidoo, G. W., Wiafe, E. A., \& Adams, A. (2018). FDI and trade policy openness in Sub-Saharan Africa. Eastern Economic Journal, 44(1), 97-116.

De Santis, R. A., \& Ehling, P. (2007). Do international portfolio investors follow firms' foreign investment decisions? Retrieved from https:// papers.ssrn.com/sol3/papers.cfm?abstract_id $=1015266$

Duarte, L. D. R. V., Kedong, Y., \& Xuemei, L. (2017). The relationship between FDI, economic growth and financial development in Cabo Verde. International Journal of Economics and Finance, 9(5), 132-142.

Dutta, N., \& Roy, S. (2011). Foreign direct investment, financial development and political risks. The Journal of Developing Areas, 303-327.

Fakhreddin, F., Nezakati, H., \& Mahmoudi Vaighan, B. (2011). The determinants of FDI inflow in manufacturing sector of Malaysia. Journal for International Business and Entrepreneurship Development, 5(4), 299-314. 
Girma, S., Gong, Y., \& Görg, H. (2008). Foreign direct investment, access to finance, and innovation activity in Chinese enterprises. The World Bank Economic Review, 22(2), 367-382.

Grossman, G. M., \& Helpman, E. (1991). Innovation and growth in the global economy. MIT press.

Hair, J., Black, W. C., Babin, B. J. \& Anderson, R. E. (2010) Multivariate data analysis (7th ed.). Upper Saddle River, New Jersey: Pearson Educational International.

Hejazi, W., \& Tang, J. (2021). Canadian FDI in a post COVID-19 world: Have we reached the tipping point? Transnational Corporations Review, 13(1), 88-108.

Ho, C. S., \& Rashid, H. A. (2011). Macroeconomic and country specific determinants of FDI. The Business Review, 18(1), 219-226.

Huong, T. T. X., Nguyen, M. L. T., \& Lien, N. T. K. (2020). An empirical study of the real effective exchange rate and foreign direct investment in Vietnam. Investment Management \& Financial Innovations, 17(4), 1.

Ismail, N. W. (2009). The determinant of foreign direct investment in ASEAN: A semi-gravity approach. Transition Studies Review, 16(3), 710 .

Kalim, R., Ali, L., \& Shahbaz, M. (2012). On Foreign Direct Investment and Stock Market Relation: A Case of Pakistan. International Journal of Economic Perspectives, 6(1).

Karim, B. A., Karim, Z. A., \& Nasharuddin, M. N. (2019). Corruption and Foreign Direct Investment (FDI) in ASEAN-5: A panel evidence. Economics and Finance in Indonesia, 64(2), 145-156.

Kariuki, C. (2015). The determinants of foreign direct investment in the African Union. Journal of Economics, Business and Management, 3(3), 346-351. 
Kasasbeh, H. A., Mdanat, M. F., \& Khasawneh, R. (2018). Corruption and FDI Inflows: Evidence from a small developing economy. Asian Economic and Financial Review, 8(8), 1075.

Kaur, M., Yadav, S. S., \& Gautam, V. (2013). Financial system development and foreign direct investment: A panel data study for BRIC countries. Global Business Review, 14(4), 729-742.

Kawai, M., \& Naknoi, K. (2017). ASEAN's trade and foreign direct investment: Long-term challenges for economic integration. The Singapore Economic Review, 62(03), 643-680.

Kinuthia, B. K., \& Murshed, S. M. (2015). FDI determinants: Kenya and Malaysia compared. Journal of Policy Modeling, 37(2), 388-400.

Lee, Y., N. (2020). Political uncertainty puts Southeast Asia's economic recovery from coronavirus at risk, expert says. Asia Politics. $C N B C$. Retrieved from https://www.cnbc.com/2020/08/10/southeast-asiaspolitical-uncertainty-threatens-economic-recovery-expert-says.html

Levine, R., \& Renelt, D. (1992). A sensitivity analysis of cross-country growth regressions. The American Economic Review, 942-963.

Liargovas, P. G., \& Skandalis, K. S. (2012). Foreign direct investment and trade openness: The case of developing economies. Social Indicators Research, 106(2), 323-331.

Loncan, T. (2021). The effects of project scale on FDI location choices: Evidence from emerging economies. Management International Review, 1-49.

Marshal, I., Solomon, I. D., \& Onyekachi, O. (2015). Bank domestic credits and economic growth nexus in Nigeria (1980-2013). International Journal of Finance and Accounting, 4(5), 236-244.

Mina, W. (2020). Do GCC market-oriented labor policies encourage inward FDI flows? Research in International Business and Finance, 51, 101092. 
Mohamed, S. E., \& Sidiropoulos, M. G. (2010). Another look at the determinants of foreign direct investment in MENA countries: An empirical investigation. Journal of Economic Development, 35(2), 75.

Nezakati, H., Fakhreddin, F., \& Vaighan, B. M. (2011). Do local banks credits to private sector and domestic direct investments affect FDI inflow? (Malaysia evidence). World Applied Sciences Journal, 15(11), 1576-1583.

Nguyen, C. P., \& Lee, G. S. (2021). Uncertainty, financial development, and FDI inflows: Global evidence. Economic Modelling, 99, 105473.

Organisation for Economic Cooperation and Development (OECD) 2020. Retrieved from https://www.oecd.org/investment/ investmentfordevelopment/1959815.pdf.

Oro, O. U., \& Alagidede, I. P. (2021). Does petroleum resources or market size drive foreign direct investment in Africa? New evidence from time-series analysis. Resources Policy, 71, 101992.

Paramati, S. R., Ummalla, M., \& Apergis, N. (2016). The effect of foreign direct investment and stock market growth on clean energy use across a panel of emerging market economies. Energy Economics, 56, 29-41.

Rajapakse, R. P. C. R. (2018). The Relationship between the Stock Market and Foreign Direct Investment (FDI) in Sri Lanka-Evidence from VAR and Co-Integration Analysis. Global Journal of Management and Business Research: B Economics and Commerce, 18(5).

Rangkakulnuwat, P., \& Paweenawat, S. W. (2015). The determinants of foreign direct investment in ASEAN. International Journal of Social Economics, 42(3), 239-250.

Raza, A., Ahmed, Z., Ahmed, M., \& Ahmed, T. (2012). The role of FDI on stock market development: the case of Pakistan. Journal of Economics and Behavioral Studies, 4(1), 26-33.

Rodrik, D. (1992). The limits of trade policy reform in developing countries. Journal of Economic Perspectives, 6(1), 87-105. 
Reiter, S.L. \& H. Kevin Steensma, H.K. 2010. Human Development and Foreign Direct Investment in Developing Countries: The Influence of FDI Policy and Corruption. World Development. 38(12): 1678-1681. https:/www.sciencedirect.com/science/article/abs/pii/ S0305750X10000926.

Shan, S., Lin, Z., Li, Y., \& Zeng, Y. (2018). Attracting Chinese FDI in Africa. Critical Perspectives on International Business, 14(2/3), 139-153.

Solow, R. M. (1957). Technical change and the aggregate production function. The review of Economics and Statistics, 39(3), 312-320.

Soumaré, I., \& Tchana Tchana, F. (2015). Causality between FDI and financial market development: Evidence from emerging markets. The World Bank Economic Review, 29(suppl_1), S205-S216.

Tsagkanos, A., Siriopoulos, C., \& Vartholomatou, K. (2019). Foreign direct investment and stock market development: Evidence from a "new" emerging market. Journal of Economic Studies. 46(1), 55-70.

UN World Economic Situation Prospects (2020). Retrieved from https:// www.un.org/development/desa/dpad/wp-content/uploads/sites/45/ WESP2020_Annex.pdf.

UNCTAD ASEAN report (2019). Retrieved from https://unctad.org/ webflyer/asean-investment-report-2019.

UNDP report (2019). Retrieved from http://hdr.undp.org/sites/default/files/ hdr2019.pdf.

Varma, S., Bhatnagar, A., Santra, S., \& Soni, A. (2020). Drivers of Indian FDI to Africa-an initial exploratory analysis. Transnational Corporations Review, 12(3), 304-318.

Van Rang, TCCT Ma Pham. (2020). The determinants of foreign direct investment in ASEAN. Retrieved from https://amp.tapchicongthuong. vn/bai-viet/the-determinants-of-foreign-direct-investment-inasean-75898.htm. 
Wang, Y. (2011). Effect of FDI in the Logistics Industry on Industrial Structure. Transnational Corporations Review, 3(1), 87-95.

Wang, P., \& Rukh, B. G. (2021). The Effect of Information Communication Technology (ICT) Infrastructure availability on FDI inflow in D8 Countries. In E3S Web of Conferences (Vol. 235). EDP Sciences.

Wang, Q., \& Wang, L. (2021). How does trade openness impact carbon intensity? Journal of Cleaner Production, 295, 126370.

Weitzel, U., Kling, G., \& Gerritsen, D. (2014). Testing the fire-sale FDI hypothesis for the European financial crisis. Journal of International Money and Finance, 49, 211-234.

Worldbank Retrieved from https://datacatalog.worldbank.org/domesticcredit-private-sector-gdp-3.

Xaypanya, P., Rangkakulnuwat, P., \& Paweenawat, S. W. (2015). The determinants of foreign direct investment in ASEAN. International Journal of Social Economics, 42(3), 239-250.

Yadav, I. S., Pahi, D., \& Gangakhedkar, R. (2019). Financial markets development and financing choice of firms: New evidence from Asia. Asia-Pacific Financial Markets, 26(4), 429-451. 